Journal of Social and Development Sciences

Vol. 2, No. 4, pp. 188-195, Oct 2011 (ISSN 2221-1152)

\title{
A Comparative Investigation of the Relation of R\&D Expenditures to Economic Growth in a Group of the Less Developed Countries and OECD Countries
}

\author{
${ }^{1}$ Mokhtari Mehran*, 2Motiee Reza \\ ${ }^{1}$ Department of management, Chalus Branch, Islamic Azad University, Chalus, Iran* \\ 2Department of management, Babol Branch, Islamic Azad University, Babol, Iran \\ *rm.search2011@gmail.com
}

\begin{abstract}
This research attend to relation between expenditures of research \& development \& economic growth in two groups of less developed \& OECD countries with a panel data model \& statistical inputs of less developed countries \& developed countries, we survey effect quantity of these expenditures on economic growth in two groups of countries. The first question appearance is that the research is more importance for OECD countries. These countries allocate huge budget to research \& development, that in 30 of OECD countries cost $\% 81$ of total R\&D of the world however, less develop countries allocate little expenditure to the part of R\&D thus coefficients of R\&D variable show that investment in research is more effected in economic growth of OECD countries as compared with less developed countries. This show that less developed countries allocate their little budgets of R\&D to ceremonial affair \& they don't pass of research stage to technology that industry needs but OECD countries can to reduce the result of this researches to productive crops, presses \& services.
\end{abstract}

Keywords: Gross Domestic Product (GDP), Organization for Economic Co-operation and Development (OECD), R\&D, Economic Growth

\section{Introduction}

Governments of industrialized countries have announced increasingly central role of science and technology at changing economic conditions. There is direct links between science, technology, economy and society. No country cannot be witness institute of destruction and own research centers. Renewal organization such centers entitled of priority much more and through educational systems and research that occurs new feelings dynamic growth. Identify existing problems, how scoping and solving problems according to policy government program is not possible without research and study. So part of any development program should be focused to organizing research and research areas. If making the easiest goods the production process is not possible without the technical knowledge, forgive new organizing to a system economic or cultural and social also cannot be thought without support of systematic research the area.In the field foreign if the goal of developing a program, be add to power of a country's national And enhance its international role and position, one of the main criteria the evaluation national in today's world, is capabilities in the areas of science and technology knowledge. Normative that every day finds more preferable and is replaced Traditional criteria national power.

Problem definition: Research is active and organized process for discovery, interpretation and revision of phenomena, events and assumptions. Research also used for usage Phenomena available to achieve Practical solutions and technologies. (R \& D) stands for two words are Research and Development. Part its research has been means definitions and a solution to a problem and all activities that is done to diagnosis, defined, analyze and solve a problem extensive research and to enforce the outcome of this research is called development. Research development is performed process during it's the results of a applied research Combination of the techniques, technology and knowledge of other and become to a product, a production process or the operation of innovation the manufacturing sectors. World technology today trend developments, especially scientific developments has been a momentum own that any moment we face the abundance of research findings and new. In such an environment organizations found that other cannot continued to just having a product or acceptable service to their survival. They know of essentials in this field having ideas and new plans to attract more viewers and this not achieved except through allocate more 
resources in the fields of research and development organizations. Research Development not only among companies and institutions but In more general look at among different countries is accepted and that ideas and more innovative designs will lead to better products and better services and such a country is able to account for a greater share of world market and compete in "knowledge production" to get a better rating. It is clear that research more effective led to increase country production, and higher domestic revenue consequently increases research contributions. What is certain is that research in today's world has of particular importance one important measure of what that developed countries the amount of credit that GDP dedicated to this. Mostafa Mokhtabad in the seventh meeting research the office of management and publications and art center refers to establishment of the Pasteur Institute in the year 1920 as start research means today. Then, Razi Institute establishment of in the year 1931 and institute "Dehkhoda Dictionary" in the year 1945 the can be considered the trend continued that in later years also continued thus that in 1951, five Research Institute, in 1961 nineteen Research Institute, in 1971 fifty Institute finally in decade to 60 eighty-six schools added the corpus research the country. To that now there are more than 460 research institutions in country licensed that are active about 80 percent. The to what extent these institutions have been able to meet the research needs of the Community seems to be requiring more precise studies, but can production of scientific papers to be considered as indicators of the institutions than 400 scientific papers in 57 years has risen to about three thousand and hundred digits in article 82 in and at least in quantitative shows development acceptable. Now Iran among 180 countries located in ratings 52 in terms of research and goals Twenty-year vision plan is reaching to first place in the Middle East and also 30 ratings gain in the whole world. On the other hand in terms of per capita research also per a million people, there are about 700 researchers in the country in comparison with other countries the figure in the American be 7 thousand and 600 and in Britain 6 million and 50 researchers per one million inhabitants.

Main research questions: The research questions are including considering the two groups of countries OECD and developing countries R \& D spending has what kind effect on their economic growth? Which group of OECD countries and developing countries R \& D spending has a greater impact on economic growth? Assumptions: Corresponding questions is intended assumptions Below: Research and development expenses have positive effect on economic growth Per 2 Groups OECD countries and developing. Effect of research and development expenses is more countries on economic growth in the OECD.

Research objectives: The objectives of this study are relationship between research and development spending with economic growth the two groups of developing countries and developed (OECD) and difference expenditure effect of research and development investment on economic growth in these two groups of OECD countries and developing countries. To gather information related research has been used of method documents or library. The direction has been used web sites and various databases. Data related to Macro variables this study is obtained the World Development Indicators (WDI).

Method data analysis: Data analysis this study will be done using Econometric software (Eviews 6.0). This way that beginning this software will enter the Data variables used in the study, and then beginning tests have stationary test the variables using unit root tests and then based on need tests have the accumulation of the variables using panel data techniques we tested assumptions about the Using the model of choice. In this study, due to related articles obtained and international being a research for estimation Model will be used panel data approach and then are interpretation results and will be paid to compare and analyze results and finally will provide need suggestions.

\section{Literature Review}

Nelson and Phelps (1966) tried to model the idea that "the main role of education is to increase people's capacity. An educated person is firstly an innovator and secondly will quickly adjust himself with new technologies and doing so will speed up spreading the technology in society. The result is faster higher productivity growth and innovation rate along with higher level of people's education. It's true especially according to the records of registration in high school and above, because the potential researchers are among these people. So in econometric models, in order to prove the effect of education on growth, registration in high school and above is used as an explanatory variable. Lucas (1988) introduced his theory of growth, based on Becker's human capital theory (1964). Lucas used a new structure of growth models 
which has concurrent effects on both physical capital and human capital. The nature of this concurrency is because of the effect of physical capital on human capital wages or human capital opportunity costs which are allocated to education sector.

Today, because of the important role of education and research on social and individual behavior and its effect on economic growth process, a new field in economics (as a science), called "educational economics" has been established and has a fast development as a response to ever increasing demands of society in relation to education and research. Decision of some people toward more research, not only improves their own benefits but also other people. Michaelowa (2000) makes an example in which a farmer is educated to use new farming technologies; eventually his neighbors will follow him (after watching his improvement). Science which is based on watching is a process which will spread the benefits of research in society. The hypothesis that "investment on education leads to economic growth" goes back to Adam Smith era (classic economists). In that era, the stress was on investment on human skills. According to Smith (1776), human will evolve into capital by suitable education and this will lead to better service and production for the society.

In a study on convergence of growth in Canadian states, Coulombe and Tremblay (2001) used Barro \& Sali model (1995) in which the full dynamic of capital in order to financially secure the human capital is assumed. Their findings show that accumulation of physical capital in Canada states (1951-1996) is a result of human capital accumulation process. The share of human capital variable in production is about 0.5 . These results show that dynamic of human capital accumulation, leads to improvements in physical capital, income and production per capita. Bassanini \& Scarpetta (2001) used Fuente \& Domenech (2000) and PMG procedure to make estimations for 21 country-members of OECD. They found a positive/meaningful relationship effect of human capital accumulation on countries' development. Also, they found out that by increasing a year in education, production per capita is increased about $6 \%$ in before-mentioned countries.

\section{Methodology}

Way that in this research is intended in order to achieve goals and test the hypothesis as cause significant is encompass a wide range of library Studies, Review documents, using economic indicators and statistical and application of econometric methods in order to estimate the model. Model used in this study is used of research Rajeev Goel et al. (2007) that to illustrate the role of research and development we use of a nonlinear production function which is based on the theoretical function Cobb - Douglas:

$$
Y=f(L, K, R) \quad(1)
$$

That high Function becomes as follows with of differential and dividing by $\mathrm{Y}$ and adding sentence fixed and disturbing Sentence:

$$
\dot{Y}_{t}=a+b_{L} \dot{L}_{t}+a_{k}\left(\frac{I_{k}}{Y}\right)_{t}+a_{R}\left(\frac{I_{R}}{Y}\right)_{t}+u_{t}
$$

Where $\dot{\boldsymbol{Y}}_{\text {r }}$ and $\dot{\boldsymbol{L}}_{\text {r }}$ respectively are economic growth rate and growth rate of labor force $\frac{I_{k}}{Y}$ and $\frac{I_{R}}{Y}$ are share capital and research and development expenses of Y. In this study interest has been of statistical methods and econometric related to this topic. Data related macro variables this study obtained of World Development Indicators (WDI). The statistical population this study is including developing countries and countries OCED. The data used for Iran will be collected of Central Bank and Statistical Center of Iran. The study analyzed data will be done using econometric software 6 Eviews. This way the beginning will into the softwared ata related to variables used in the study,and then will be paid to test the model. In this study, for estimated model will be used method Data Panel3 and then be interpreted results for two groups of countries and will be paid to compare and analyze the results this two groups and finally was presented need advice proportional to the Iranian economy.

Data processing: Development Organization and Economic Cooperation (OECD) Organization economic Cooperation and development which is headquartered in Paris. Is referred as club of rich countries, research Center, regulatory institution and non-academic university Organization economic Cooperation and Development at December 14, 1960? Signed convention 21, a substance founded by countries Austria, 
Belgium, Canada, Denmark, France, Germany, Greece, Iceland, Ireland, Luxembourg, Netherlands, Norway, Portugal, Spain, Sweden, Switzerland, Turkey, Britain and the United States. Later with the accession countries, Italy, Japan, New Zealand, Finland, Australia, Check Republic, Hungary, Mexico, South Korea, Poland and Slovak Republic the number of members increased 30 country5.

Table 1: Share of spending R \& D of GDP in countries OECD in 2005 or latest available year.

\begin{tabular}{llllll}
\hline $\begin{array}{l}\text { Countries } \\
\text { Economic - Political } \\
\text { groups }\end{array}$ & $\begin{array}{l}\text { Share } \\
\text { of } \\
\text { GDP }\end{array}$ & $\begin{array}{l}\text { Countries / Economic } \\
\text { - Political groups }\end{array}$ & $\begin{array}{l}\text { Share } \\
\text { of } \\
\text { GDP }\end{array}$ & $\begin{array}{l}\text { Countries / Economic } \\
\text { - Political groups }\end{array}$ & $\begin{array}{l}\text { Share } \\
\text { of } \\
\text { GDP }\end{array}$ \\
\hline OECD Countries & 2.25 & Taiwan (2004) & 2.42 & Spain (2005) & 1.12 \\
(2004) & & & & & \\
Europe Union (2004) & 1.77 & Singapore (2005) & 2.36 & Italy (2005) & 1.10 \\
Israel (2005) & 4.71 & France (2005) & 2.13 & Russia (2005) & 1.07 \\
Sweden (2005) & 3.86 & Canada (2006) & 1.95 & Hungary (2005) & 0.94 \\
Finland (2006) & 3.51 & Belgium (2006) & 1.82 & South Africa (2005) & 0.87 \\
Japan (2004) & 3.18 & Netherlands (2004) & 1.78 & Portugal (2006) & 0.81 \\
South Korea (2005) & 2.99 & Australia (2004) & 1.77 & Turkey (2005) & 0.67 \\
Switzerland (2005) & 2.93 & Luxembourg (2005) & 1.56 & Greece (2004) & 0.61 \\
Iceland (2003) & 2.86 & Norway (2005) & 1.51 & Poland (2005) & 0.57 \\
United States (2006) & 2.57 & Czech (2005) & 1.42 & Slovakia (2005) & 0.51 \\
Germany (2005) & 2.51 & Ireland (2005) & 1.25 & Argentina (2005) & 0.46 \\
Austria (2006) & 2.44 & Slovenia (2005) & 1.22 & Mexico (2003) & 0.43 \\
Denmark (2005) & 2.44 & New Zealand (2003) & 1.14 & Romania (2004) & 0.39 \\
\hline
\end{tabular}

Source: OECD website

Table 1 shows the share of $\mathrm{R} \& \mathrm{D}$ spending of national product in countries group OECD. So that OECD countries in 2004 equivalent is equal to $5.2 \%$ of GDP have been allocated to the research and development. Among these countries in research and development Israel and Sweden have used the highest GDP and countries like Romania and Mexico and Argentina the lowest GDP have been devoted to the research. Model estimation results for countries OECD member: Like model estimates for OPEC countries here, too, estimation model is through three methods of accumulating data (Pooling data), method fixed effects and method random effects the results of these three methods is shown in Table 2. In order to determine the optimal model between three accumulated data, fixed effects and random effects we use F test and Hasman test For this purpose the F statistics get of the model estimated:

$F=\frac{(691.08-456.37) /(23-1)}{456.37 /(230-23-3)}=4.78$

Since value obtained for $\mathrm{F}$ larger Of Table number $\left(F_{23,3, \% 0.05}=1.59\right)$ in significance level is $05.0 \%$ result null hypothesis is rejected and should be used method fixed effects or random affects Method. The next issue is that we must identify model in which one of fixed effects model and random effects is the ability expressed and evaluated. Therefore, in order to choose between two fixed effects or random effects methods have done Hasman the test. Since the test statistic Hasman the statistics in Table $\chi^{2}=53.41$ the significance level is less $5 \%$ null hypothesis is rejected and using fixed effects will be more efficient. We assume that a research cost is equal to RD and workforce growth is LABG and investment growth is INV.

The results of the Interpretation estimated Model by Method fixed effects for OECD countries model show that Significant variable R\&D and its coefficient are equal to 1.223 and this, own has proved the research hypothesis and shows that has a positive effect research and development expenses on economic growth in member countries of OECD. Also the coefficient this is indicative that investment in Research has more effective role in economic growth in OECD countries toward developing countries. And these countries wellmanaged results from a study of the application with these techniques, technologies and knowledge of other been incorporated and a product a production process or innovation useable in the manufacturing sector conversion and the results of scientific research make tangible in the community. 
Table 2: Results of model estimates for OECD countries

\begin{tabular}{|c|c|c|c|c|c|c|}
\hline \multirow[t]{2}{*}{ Variables } & \multicolumn{2}{|c|}{ Method of pooling data } & \multicolumn{2}{|c|}{ Method fixed effects } & \multicolumn{2}{|c|}{ Method random effects } \\
\hline & $\begin{array}{l}\text { variable } \\
\text { Coefficient }\end{array}$ & $\begin{array}{l}\text { t-statistics } \\
\text { (Prob.) }\end{array}$ & $\begin{array}{l}\text { variable } \\
\text { Coefficient }\end{array}$ & $\begin{array}{l}\text { t-statistics } \\
\text { (Prob.) }\end{array}$ & $\begin{array}{l}\text { variable } \\
\text { Coefficient }\end{array}$ & $\begin{array}{l}\text { t-statistics } \\
\text { (Prob.) }\end{array}$ \\
\hline C & 1.426 & $5.260(0.0000)$ & -1.184 & $-2.314(0.216)$ & 1.191 & $3.151(0.001)$ \\
\hline LABG & 66.737 & $7.413(0.000)$ & 18.478 & $20210(0.028)$ & 68.924 & $6.890(0.000)$ \\
\hline INV & $5.7 \mathrm{E}+08$ & $2.424(0.016)$ & $7.05 E+09$ & $3.799(0.002)$ & $6.77 \mathrm{E}+08$ & $2.168(0.031)$ \\
\hline \multirow[t]{2}{*}{ RD } & 0.273 & $2.318(0.021)$ & 1.223 & $7.290(0.000)$ & 0.427 & $2.701(0.007)$ \\
\hline & \multicolumn{2}{|c|}{ F-statistic=17.815, } & F-statistic $=15.709$, & $\begin{array}{l}R^{2}=0.616 \\
709\end{array}$ & $\begin{array}{l}\mathrm{R}^{2}=0.352, \mathrm{~A} \\
\mathrm{~F} \text {-statistic }= \\
\mathrm{SSR}=691.08\end{array}$ & \\
\hline
\end{tabular}

Status of research in developing countries: Today, in developed countries research is a long-term investment and universities the highest priority is assigned to nurture talent and education Students and what is remarkable in this priorities close relationship between educations is in economic growth. The increasing rate of economic growth obtained with support higher education and science in universities. According to UNESCO statistics 1997 developed countries have 84\% of global investment in R \& D and 72 percent of the world's researchers and have allocated to 88 percent scientific output registered in the Science Citation Index. Nevertheless, science in developing countries considered to be as a marginal issue, or even decorative! The reality is that not know most developing countries that can improve their position with promotion science and technology. Although some of these countries are aware of the importance of science and technology, inadequate scientific infrastructure, provides many obstacles in the way scientific Development these communities. Lack of human resources and infrastructure scientific Development in these communities and investment rate in these categories indicates the how is ignored science and technology in these countries. Ratio number of researchers to total population in developed countries is much more the ratio of in developing countries. In this study, tried is that some of these countries that are the best and most complete data in the field Research development spending be chosen so that this group of countries that are be with more advanced economies among the developing nations and United Nations classifications have been classified among groups of middle-income countries. However, there is a not still thoroughly established sign of a developed country. The tried are that of all continents of the world there is an example of these countries. In other words, is used of cluster sampling to select our sample.

Table 3: Average research costs as a percentage of GDP during the years 2008-99 AD in some developing countries

\begin{tabular}{|c|c|c|c|}
\hline Country & percentage of research costs & Country & percentage of research costs \\
\hline Iran & 0.46 & Macedonia & 0.32 \\
\hline Argentina & 0.42 & Mauritania & 0.34 \\
\hline Belarus & 0.72 & Mexico & $\frac{\circ}{\circ} 0.38$ \\
\hline Brazil & 0.95 & Poland & 0.62 \\
\hline Bulgaria & 0.51 & Romania & 0.45 \\
\hline Chile & 0.56 & Russian Federation & $\frac{8}{2} 1.09$ \\
\hline Columbia & 0.22 & Serbia & $\frac{\circ}{1} 1.57$ \\
\hline Costa Rica & 0.32 & Turkey & 0.59 \\
\hline Kazakhstan & 응 023 & Venezuela & $\frac{\circ}{2} 0.38$ \\
\hline Lithuania & 0.62 & Uruguay & 0.27 \\
\hline
\end{tabular}

Source: UNESCO

Results estimated Model for Selected of developing countries: For this purpose estimated Model will be through three methods of data accumulation (Pooling data), Method fixed effects and random affects that these three is given in Table 3. In order to determine the optimal estimated Model between three accumulated data, fixed effects and random effects we use of following tests. In the first test (test of equality width of origin), in order to determine the optimal estimated model, first, it is necessary through the first test 
we examined equality width of origin between countries and choose do between Method pooling data and panel data.

$$
\left\{\begin{array}{l}
H_{0}: \alpha_{1}=\alpha_{2}=\ldots=\alpha_{N} \\
H_{1}=\alpha_{i} \neq \alpha_{j}
\end{array} \quad i \neq j\right.
$$

The test statistic is description of $\mathrm{F}$ and the such that we encounter with two estimated model bound and unbound , that in Bound model, width of origin are constant and equal.

$$
F=\frac{\left(S S R_{R}-S S R_{U R}\right) /(N-1)}{S S R_{U R} /(N T-N-K)}
$$

We will have, with placement of numbers obtained from the estimate $F=1.08$. The statistic we compare with statistics in Table in significance level of $5 \%$ because these statistics is smaller of statistics table 4 one hypothesis is rejected and thus should be used method pooling data.

Table 4: Results of estimated Model for developing countries

\begin{tabular}{lllllll}
\hline variables & pooling data Method & fixed effects Method & \multicolumn{2}{l}{ random effects Method } \\
\hline & $\begin{array}{l}\text { Coefficient } \\
\text { variable }\end{array}$ & $\begin{array}{l}\text { t-ststistic } \\
\text { (Prob.) }\end{array}$ & $\begin{array}{l}\text { Coefficient } \\
\text { variable }\end{array}$ & $\begin{array}{l}\text { t-ststistic } \\
\text { (Prob.) }\end{array}$ & $\begin{array}{l}\text { Coefficient } \\
\text { variable }\end{array}$ & $\begin{array}{l}\text { t-ststistic } \\
\text { (Prob.) }\end{array}$ \\
\hline C & -0.21 & $-4.56(0.000)$ & 0.098 & $1.28(0.201)$ & -0.16 & $-0.66(0.005)$ \\
LABG & 0.84 & $18.12(0.000)$ & 0.83 & $14.13(0.000)$ & 0.86 & $17.03(0.000)$ \\
INV & 0.011 & $5.72(0.000)$ & 0.018 & $(7.52(0.000)$ & 0.0079 & $0.77(0.043)$ \\
RD & 0.042 & $0.85(0.003)$ & -0.76 & $-6.16(0.000)$ & 0.104 & $0.67(0.049)$ \\
\hline & $R^{2}=0.965$, Adj. $R^{2}=0.964$ & $\mathrm{R}^{2}=0.984$, Adj.R ${ }^{2}=0.982$ & $\mathrm{R}^{2}=0.982$, Adj. $\mathrm{R}^{2}=0.982$ \\
& F-statistic=195.09, SSR=108.9 & F-statistic $=564.54$, SSR $=92.81$ & F-statistic=3955, \\
& & & & & \multicolumn{2}{l}{ SSR=103.829 } \\
\end{tabular}

Source: Output software

Interpretation of estimated Model by Method fixed effects for developing countries: The results obtained gives of estimated coefficient of 0.042 for the variable RD. That shows research and development expenditure in developing countries has had a positive effect on economic growth that will be approved the research hypothesis. But its effect is low on economic growth. Indicating that science in developing countries considered to be as a marginal issue or even decorative. The fact is most developing countries do not know to advancing science and technology can improve their position and if they are aware of the importance of this issue due to the weakness of the administrative not used research and studies conducted in developing in other words, no use deposits are to libraries and they only use is used in further research.

Discussion: According to fourth Development Plan is predicted until year 88 equivalent to 2 percent of gross domestic product (GDP) allocated to research. But the budget in recent years has been considered for research all has been less than one percent of GDP. It seems that the with this number, to achieve the Fourth Program goals we encounter with serious problems and this while that even some of our neighbors allocated digit about 3 percent of GDP to this.

Evaluation research the situation in Iran during 2005-2009 shows that Position and role of research is not considered so good. The Fourth Program Law the share of research funds of GDP of the public funds equivalent 2 percent and the location operating income governmental companies, banks and profit-making institutes affiliated to the government and non-public sector equivalent of one percent targeted by is until end the program. The share of research funds of GDP of the public funds in 1383 has been equivalent to 56 hundredths percent that to achieve program aims the 2 percent in 2009 should be at least equal to 72 hundredths percent in 2005. Since the accurate Credit paid research it is not clear in the 1384 report, so 
research grants approved in 2005 it is considered that its ratio to GDP has been equivalent to six hundredths percent and is represents 84 percent of achieving program aims.

Table 5. Ratio public research funds to GDP in the fourth development plan

\begin{tabular}{llll}
\hline year & Fractional than program & Relative to GDP & \\
\cline { 4 - 4 } & & Performance & program \\
\hline 2005 & 0.16 & 0.72 & 0.6 \\
2006 & 0.23 & 0.84 & 0.64 \\
2007 & 0.43 & 1.13 & 0.65 \\
2008 & 0.7 & 1.5 & 0.45 \\
2009 & 0.8 & 2 & 0.4 \\
\hline
\end{tabular}

Source: Islamic Consultative Assembly, the law of fourth five-year plan

The Ratio, only a small part of the objectives, has been according Fourth Program Law but in the development of research and Technology other indices targeting is for the that because, no a comprehensive statistical system for efficient in research and technology, no information is of numbers related to variable part, to be able to evaluated the achieving these indicators.

\section{Conclusion}

The results obtained from estimating the model indicates that at first in two groups of countries has been positive variable coefficient of $R$ \& $D$ this shows investment in technical knowledge reserves can be remembered it in the form research and development expenses, in increase economic growth and increase the productive capacity of these countries has been a significant role. Second is that in developing member countries variable coefficient of R \& D (R \& D spending a share of GDP is an indicator.) have been equal to 0.042 . Smaller is than the number obtained to the countries of OECD (equal to 22.1). And this indicates that investment In Research has been more effective role in economic growth of countries, OECD, than developing countries. This is because the in developed countries of the Planning and Policy (Research Development), they have put part of the macro policies of their governments.

The results obtained from estimating the model indicates that at first in two groups of countries has been positive variable coefficient of $\mathrm{R} \& \mathrm{D}$ this shows investment in technical knowledge reserves can be remembered it in the form research and development expenses, in increase economic growth and increase the productive capacity of these countries has been a significant role. Second is that in developing member countries variable coefficient of R \& D (R \& D spending a share of GDP is an indicator.) have been equal to 0.042 . Smaller is than the number obtained to the countries of OECD (equal to 22.1). And this indicates that investment In Research has been more effective role in economic growth of countries, OECD, than developing countries. This is because the in developed countries of the Planning and Policy (Research Development), they have put part of the macro policies of their governments.

\section{References}

Barro, R.,\& Sala-i-Martin, X. (1995). Economic Growth. McGraw-Hill.

Bassanini, A., \& Scarpetta, S. (2001). Does Human Capital Matter for Growth in OECD Countries? Evidence from Pooled Mean-Group Estimates; OECD, Economics Department. Working Paper, 282.

Becker, G. S. (1964). Human capital, Fertility, and economic growth. Journal of Political Economy, 98(5), 2.

Coulombe, S., \&Tremblay, J. F. (2001). Human Capital and Regional Convergence in Canada. Journal of Economic Studies, 28(3), 154-180.

Fuente, A., \&Doménech, R. (2000). Human capital in growth regressions: how much difference does data quality make? CEPR Discussion Paper 2466.

Lucas, R., E. (1988). On the Mechanics of Economic Development. Journal of Monetary Economics, 22(1), 3-42. 
Michaelowa, A. (2000). Options for making small scale CDM project more attractive. Hamburg Institute of International Economics. Germany.

Nelson, R.,\& Phelps, E. (1966). Investment in humans, technological diffusion, and economic growth. American Economic Review: Papers and Proceedings, 56(2), 69-75.

Rajeev, K., Goel, J. E., \&Payne, R. R. (2008). R\&D expenditures and U.S. economic growth: A disaggregated approach. Journal of Policy Modeling, 30(2), 237-250.

Smith, A. (1776). An Inquiry Into the Nature and Causes of the Wealth of Nations, ed. R. H. Campbell and A. S. Skinner (Oxford: Oxford university Press, 1976 [orig. Pub. 1776]), Book IV. Hereafter Referred to as WN. 